\title{
Resveratrol derivatives potently induce apoptosis in human promyelocytic leukemia cells
}

\author{
Ji Hyun Kang ${ }^{1}$, Youn Hee Park ${ }^{1}$ \\ Sang Won $\mathrm{Choi}^{2}$, Eun Kyoung Yang \\ and Won Jung Lee $e^{1,3}$ \\ 'Department of Physiology \\ School of Medicine \\ Kyungpook National University \\ Daegu 700-422, Korea \\ ${ }^{2}$ Department of Food Science and Nutrition \\ Cahnolic University of Daegu \\ Hayang, Gyeongbuk 712-702, Korea \\ ${ }^{3}$ Corresponding author: Tel, 053-420-4811; \\ Fax, 053-424-3349; E-mail, wleek@knu.ac.kr
}

Accepted 25 September 2003

Abbreviations: CYP, cytochrome P450; HL-60, human promyelocyfic leukemia

\begin{abstract}
Resveratrol has been shown to possess antioxidant and anticancer activities, but little is known on the effect of resveratrol derivatives. Recently we have isolated resveratrol and its dimers and trimers from peony (Paeonia lactifiora) seeds, and reported their strong antioxidant and cytotoxic activity. In the present study, we have evaluated cellular effects of resveratrol derivatives; viniferin, gnetin $\mathbf{H}$, and suffruticosol $B$ on the proliferation and apoptosis in HL-60 cells in vitro. All resveratrol and its derivatives reduced viability of HL-60 cells in a dose-dependent manner with their IC ${ }_{50}$ values of $20-90 \mu \mathrm{M}$. Ascending orders of IC 50 values were suffruticosol $B$, gnetin $H$, viniferin and resveratrol respectively. $\mathrm{HL}-60$ cells treated with the four stilbenes exhibited the distinct morpholo. gical changes characteristics of cell apoptosis such as chromatin condensation, apoptotic bodies, and DNA fragmentations. A time-dependent histogram of the cellular DNA analyzed by flow cytometry revealed a rapid increase in subdiploid cells and a concomitant decrease in diploid cells exposed to $100 \mu \mathrm{M}$ resveratrol for $0-24 \mathrm{~h}$. Cells treated with $25 \mu \mathrm{M}$ of resveratrol, viniferin, gnetin $\mathrm{H}$, and suffruticosol $B$ for $24 \mathrm{~h}$ resulted in increment of sub-G1 population by $51,5,11$ and $59 \%$, respec-
\end{abstract}

tively. Treatment of cells with $0.20 \mu \mathrm{M}$ resveratrol for $5 \mathrm{~h}$ produced a concentration-dependent decrease in cytochrome P450 (CYP) $1 B 1$ mRNA levels. Suffruticosol B also suppressed CYP1B1 gene expression. These results demonstrated that resveratrol oligomers also strongly suppressed HL-60 cell proliferation, and induced DNA damage. In addition, CYP1B1 gene supression may suggest an involvement in the resveratrol-induced apoptosis in HL -60 cells.

Keywords: antioxidants; apoptosis; cell death; neoplasm; paeonia

\section{Introduction}

Resveratrol, trans-3,5,4'-hydroxystilbene, is a naturally occurring phytoalexin and a polyphenolic compound. Resveratrol has estrogenic activity in mammals (Gehm et al., 1997; Bowers et al., 2000) and therefore is classified as a phytoestrogen. Resveratrol has recently attracted considerable interest because of its inhibitor activity on multiple cellular events associated with carcinogenesis (Jang et al., 1997; Runqing et al., 1999). Resveratrol has been shown to have potent growth inhibitory effects on various cancer cells such as colonic tumor cells (Schneider et al., 2000), leukemic cells (Gautam et al., 2000; Dorrie et al., 2001), breast and prostate cancer cells (Mitchell et al., 1999; Damianaki et al., 2000), and has been suggested as one of the most promising cancer chemopreventive agents.

Resveratrol was found to be present in a number of plant species including grapes and peanuts. Recently we have isolated resveratrol and its dimers and trimers such as viniferin, gnetin $\mathrm{H}$, and suffruticosol $\mathrm{A}$ and $\mathrm{B}$ from peony (Paeonia lactiflora) seeds, known as one of the richest sources of various resveratrol derivatives (Figure 1; Kim et al., 2002a). Resveratrol oligomers have thus far been isolated mainly from five plant families, namely Dipterocarpaceae, Vitaceae, Cyperaceae, Gnetaceae and Leguminosae. Most of resveratrol oligomers in plants were formed from resveratrol or viniferin by dehydrogenation and Diels Alder reaction (Sotheeswaran and Pasupathy 1993). Resveratrol oligomers like the monomer are known to exert strong antioxidant activity (Bernard et al., 1997; Wang et al., 1999; Kim et al., 2002a) and to inhibit growth of several cancer cell lines (Ohyama et al., 
<smiles>Oc1ccc(/C=C/c2cc(O)cc(O)c2)cc1</smiles>

trans-Resveratrol

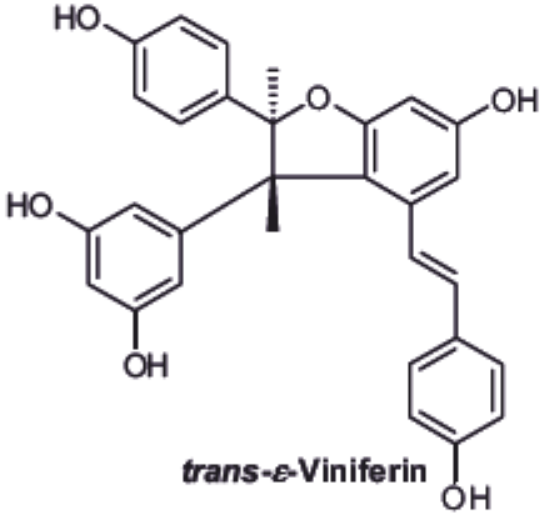

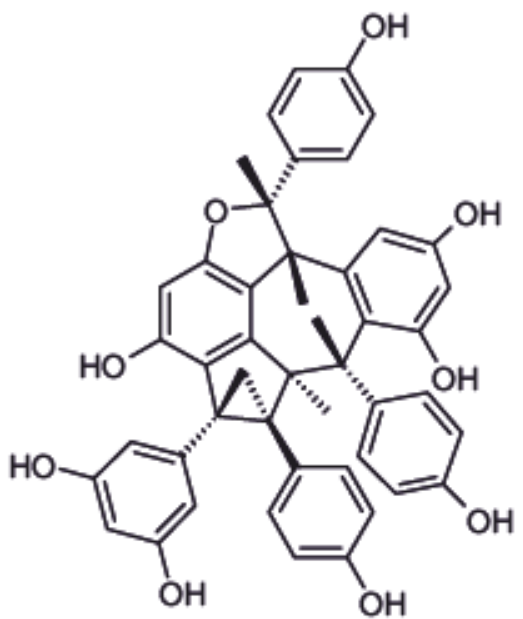

Suffruticosol B

Figure 1. Chemical structure of resveratrol and its oligomers.

1999; Kim et al., 2002b). However, very little is known on the mechanism of antiproliferative effects of resveratrol derivatives on cancer cells.

Recent studies were focused on the apoptosis of cell death, as a probable target mechanism of reservatrol on cancer cells. Apoptosis is a genetically controlled response of an intrinsic cellular system that is required for a critical balance between cell proliferation and cell death in normal development and maintenance of homeostasis of organisms (Krammer et al., 1994). Many chemotherapeutic agents suppress growth of transformed or malignant cells by inducing apoptosis (Thompson et al., 1995; Hannun, 1997; Park et al., 1997). An induction of tumor cell apoptosis is one of the efficient target for drug development (Shi et al., 1996; Watabe et al., 1996) and has become a major focus in the study of cancer therapy (White, 1996). The present study showed that resveratrol dimers and trimers isolated from peony seeds inhibit the growth and induce apoptosis in human leukemia $\mathrm{HL}-60$ cells.

\section{Materials and Methods}

\section{Chemicals}

Propidium iodide (PI), 3-(4,5-dimethylthiazol-2-yl)-2, 5-diphenyl tetrazolium bromide (MTT) and RNAse A were purchased from Sigma Chemical Co. (St. Louis, MO). FBS was from Hyclone (Logan, UT). Antibioticsantimycotes, RPMI 1640 and trypsin-EDTA were from Gibco BRL (Gland Island, NY). Hoechst 33342 was from Calbiochem (San Diego, CA). Resveratrol and its derivatives were isolated from seeds of Paeonia lactiflora Pall and their chemical structures were confirmed by mass and nuclear magnetic resonance spectroscopy as described previously (Kim et al., 2002a). Stock solution of resveratrol and its derivatives were made in DMSO at a concentration of 
$10 \mathrm{mmoVI}$.

\section{Cell culture and cytotoxicity assay}

Human promyelocytic leukemia (HL-60) cells were maintained at $37^{\circ} \mathrm{C}$ in a humidified atmosphere of $5 \%$ $\mathrm{CO}_{2}$ in RPMI 1640 supplemented with $10 \%$ heat inactivated FBS, $20 \mathrm{mM}$ Hepes $(\mathrm{pH} 7.0)$ and $1 \%$ antibiotic-antimycotic. The cytotoxic effect of resveratrol and its derivatives was analyzed by $\mathrm{MTT}$ assay, which was known as a method to determine the viability of cells by staining viable cells with MTT. For MTT assay, HL-60 $\left(5 \times 10^{4}\right.$ cell/well) were grown for 2 days with serial dilutions of resveratrol derivatives in 96 well plate. After incubation, $50 \mu \mathrm{l}$ of MTT solution $(1.1 \mathrm{mg} / \mathrm{ml})$ was added to each well and then incubated for an additional $4 \mathrm{~h}$. After centrifugation, the supernatant was removed from each well. The colored formazan crystal produced from MTT was dissolved in $150 \mu \mathrm{l}$ of DMSO and then the optical density value was measured at $540 \mathrm{~nm}$ by a plate reader (Multiscan MCC/340, Labsystem, Finland).

\section{Morphological examination}

HL-60 cells $\left(1 \times 10^{6}\right.$ cells $\left./ \mathrm{ml}\right)$ grown in a 6 -well plates were treated with $100 \mu \mathrm{M}$ of four stibenes at $37^{\circ} \mathrm{C}$ for $24 \mathrm{~h}$. Morphological changes occurring in the cells were observed under phase-contrast microscope and photographed. Ultrastrutual examination was performed by conventional techniques using a biological inverted microscope (Nikon T-300, Tokyo, Japan). For nuclear staining, HL-60 cells $\left(1 \times 10^{6}\right.$ cells $\left./ \mathrm{ml}\right)$ were cultured in a 6-well plates in RPMI 1640 medium containing $10 \% \mathrm{FBS}$ in the absence or presence of $25 \mu \mathrm{M}$ resveratrol and its derivatives. After $24 \mathrm{~h}$, cells were stained with the DNA specific fluorochrom Hoechst $33342(10 \mu \mathrm{M})$ for $30 \mathrm{~min}$, and observed under fluorescent microscopy (Axioplan2 imaging and Aiophot2 Universal Microscope, Zeiss, Hallbergmoos, Germany).

\section{Analysis of DNA fragmentation}

HL-60 cells at a density of $1 \times 10^{6}$ cells $/ \mathrm{ml}$ were treated with $25 \mu \mathrm{M}$ resveratrol and its derivatives for $24 \mathrm{~h}$, respectively. The isolation of apoptotic DNA fragments was performed as described by Herrmann et al. (1994). Briefly, the cells were harvested by centrifugation at $1,200 \mathrm{rpm}$ for $3 \mathrm{~min}$ and then treated with a lysis buffer ( $1 \%$ Nonidet P-40, $20 \mathrm{mM}$ EDTA, $50 \mathrm{mM}$ Tris- $\mathrm{HCl}, \mathrm{pH}$ 7.5). After centrifugation for 5 min the supernatant was collected and brought to $1 \%$ SDS and treated for $2 \mathrm{~h}$ at $50^{\circ} \mathrm{C}$ with RNase $\mathrm{A}$ and subsequently with proteinase $\mathrm{K}$ for $2 \mathrm{~h}$ at $37^{\circ} \mathrm{C}$. The DNA fragments were precipitated with 2.5 volumes of ethanol in the presence of $5 \mathrm{M}$ ammonium acetate.
The DNA fragmentation was visualized by electrophoresis on a $1.6 \%$ agarose gel.

\section{Flow cytometry analysis}

HL-60 cells were either untreated or treated with 25 $\mu \mathrm{M}$ or $100 \mu \mathrm{M}$ resveratrol and its derivatives for 24 h. After these treatments, approximately $1 \times 10^{6}$ cell pellets were prepared and washed twice with PBS without $\mathrm{Ca}^{2 *}$ and $\mathrm{Mg}^{2 *}$ plus $2 \%$ FBS, suspended in $100 \mu \mathrm{l}$ of PBS, and then $200 \mu \mathrm{l}$ of $95 \%$ cold ethanol was added while vortexing. The cells were incubated at $4^{\circ} \mathrm{C}$ for $1 \mathrm{~h}$, washed twice with PBS containing $2 \%$ FBS and resuspended with $12.5 \mu \mathrm{g}$ of RNase in 250 $\mu \mathrm{l}$ of $1.12 \%$ sodium citrate buffer $(\mathrm{pH} 8.45)$. Incubation was continued at $37^{\circ} \mathrm{C}$ for 30 min before staining of the cellular DNA with $250 \mu$ of propidium iodide (50 $\mu \mathrm{g} / \mathrm{ml}$ ) for $30 \mathrm{~min}$ at $4^{\circ} \mathrm{C}$. The stained cells were analyzed on a fluorecent activated cell sorter (FACScan) flow cytometer (Becton \& Dickinson, San Jose, CA) for the relative DNA content, based on an increased red fluorescence.

\section{Isolation of tatal RNA and reverse transcription-PCR}

Total RNA was isolated from HL-60 cells using the Trizol $^{\mathrm{TM}}$ reagent according to the manufacturer's protocol. Ten $\mu \mathrm{g}$ of RNA was reverse transcribed by oligo (dT)15 primer and M-MLV reverse transcriptase for $90 \mathrm{~min}$ at $37^{\circ} \mathrm{C}$. Sequences for the forward (5'CAC-TGC-CAA-CAC-CTC-TGT-CTT-3') and reverse (5'-CAA-GGA-GCT-CCA-TGG-ACT-CT-3') PCR primer for cytochrome P450 (CYP)1B1 (Tomas et al., 2000) and those for the forward (5'-TGA-GAA-CGG-GAAGCT-TGT-CA-3') and reverse (5'-GGA-AGG-CCA-TGCCAG-TGA-3') primers for GAPDH were used. PCR amplification for CYP1B1 was performed 25 cycles (denaturation at $95^{\circ} \mathrm{C}$ for $30 \mathrm{~s}$, annealing at $59^{\circ} \mathrm{C}$ for $30 \mathrm{~s}$, polymerization at $72^{\circ} \mathrm{C}$ for $45 \mathrm{~s}$ ). The reactions for GAPDH were performed 25 cycles (denaturation at $95^{\circ} \mathrm{C}$ for $1 \mathrm{~min}$, annealing at $56^{\circ} \mathrm{C}$ for $1 \mathrm{~min}$, polymerization at $74^{\circ} \mathrm{C}$ for $90 \mathrm{~s}$ ). The amplified cDNA by PCR was visualized by electrophoresis in $1 \%$ agarose gel in the presence of ethidium bromide. The band was quantified using the NIH Image analysis program (NIH, Betheda, MD). The scale of each band was expressed as a ratio of the optical intensity of the CYP1B1 band to that of the GAPDH band.

\section{Results}

\section{Cytotoxic effect of resveratrol and its derivatives on HL-60 cells}

The effects of resveratrol and its derivatives on the 


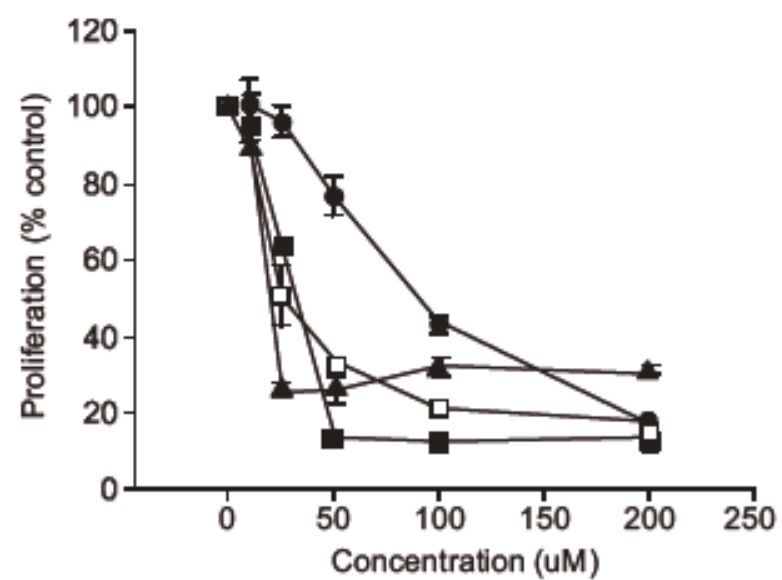

Figure 2. Cybtoxic effect of resveratrol $(\bullet)$, viniferin $(\square)$, gnetin H (A) and suffrufocosol B ( $\square$ ) on the growth of HL-60 cells. Cells were grown for $24 \mathrm{~h}$ in the presence or absence of different amounts of four sflbenes $(10,25,50,100,200 \mu \mathrm{M})$. Error bars represent standard error of assays from 6 replicale experiments.

viability of HL-60 cells determined by MTT assay are shown in Figure 2. When cells were incubated with several doses of resveratrol and its derivatives, ranging from 10 to $200 \mu \mathrm{M}$ for $24 \mathrm{~h}$, cell viability was decreased in a dose-dependent manner. The concentrations of resveratrol and its derivatives needed to inhibit cell growth of $\mathrm{HL}-60$ cells were quite low. Their $\mathrm{IC}_{50}$ values in ascending order were suffruticosol $\mathrm{B}$, gnetin $H$, viniferin and resveratrol $(20,25,33$, and 95 $\mu \mathrm{M}$, respectively).

\section{Apoptosis induced by trans-resveratrol and its derivatives}

$\mathrm{HL}-60$ cells treated with $100 \mu \mathrm{M}$ resveratrol and its derivatives for $24 \mathrm{~h}$, stained with a DNA binding dye Hoechst 33342 and morphological changes were examined with fluorescence microscope, exhibited typical morphological features of apoptosis such as chromatin condensation, the nuclei fragmentation into various sizes and collapse of the cell in to apoptotic body (Figure $3 \mathrm{~A}$ ). DNA fragmentation was evident in most cells as seen by the induction of DNA strandbreakage (Figure 3B). Agarose gel electrophoresis of DNA from the HL-60 cells incubated with resveratrol and its oligomers showed internucleosomal DNA degradation into oligonucleosomal sizes, ranging from $185 \mathrm{bp}$ and its multiples up to $2,500 \mathrm{bp}$.

Flow cytometric analysis of DNA content again corroborated the apoptotic state of the treated cells. Time course histograms of DNA content in cells treated with $100 \mu \mathrm{M}$ resveratrol for various periods of time showed a rapid increase in the sub-G1 peak of cells and a concomitant decrease in diploid cells as
A
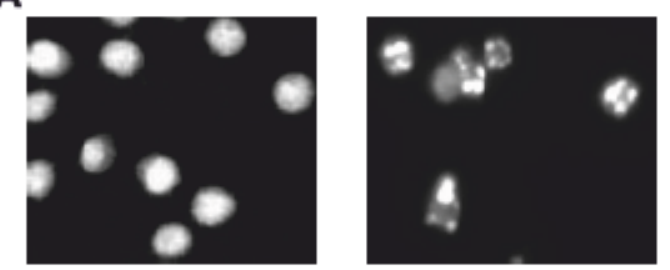

B

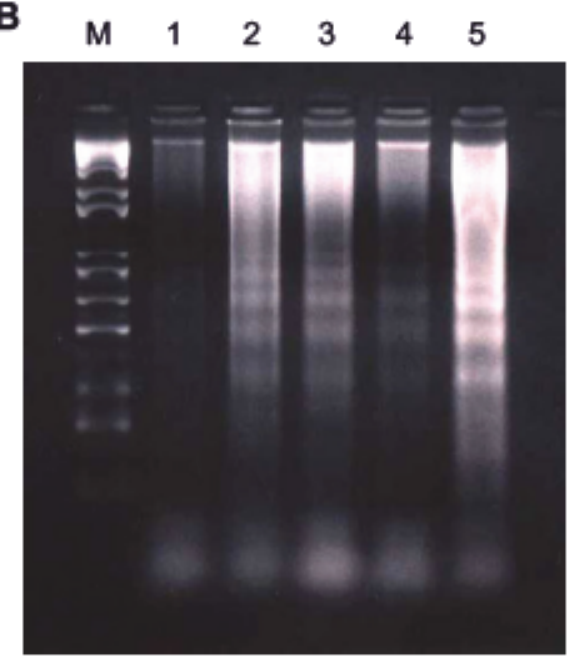

Figure 3. Resveratrol derivafives-induced apoplosis in HL-60 cells. (A) Representative nuclear morphology of HL-60 cells grown for 24 $h$ in the absence (left) or presence (right) of $25 \mu \mathrm{M}$ resveratrol or its derivatives, and stained with bisbenzimide (Hoechst 33324). Nuclei of cells untreated or treated with resveratrol oligomers were assessed in an Axioplan2 imaging fuorescence. (B) Nucleosomal DNA ragmentafion of HL-60 cells after $24 \mathrm{~h}$ exposure b $25 \mu \mathrm{M}$ resveratrol (lane 2), viniferin (lane 3), gnetin $H$ (lane 4) and suf futicosol B (lane 5). Lane M represents $1-\mathrm{kb}$ ladder used as a molecular marker. Lane 1. The DNA fragmentation was analyzed by NP-40 lysis method using $1.6 \%$ agarose gel electrophoresis and staining with ethidium bromide.

$\mu \mathrm{M}$ resveratrol, viniferin, gnetin $\mathrm{H}$, and suffruticosol B for $24 \mathrm{~h}$, the percentage of cell populations with subdiploid DNA content increased to $51,5,11$ and 59 , respectively (Figure 4 ). With a higher concentration of $100 \mu \mathrm{M}$, the subdiploid cells increased to $>60 \%$ of cells treated with resveratrol, viniferin and suffruticosol B, but was about $35 \%$ of cells treated with gentin $\mathrm{H}$.

\section{Effects of resveratrols on CYP1B1 mRNA expression}

The possible influence of resveratrol and its oligomers on the constitutive CYP1B1 gene expression was investigated. RT-PCR analysis of the concentrationresponse experiment showed that CYP1B1 mRNA level decreased approximately $30 \%$ at higher doses of 10-20 $\mu \mathrm{M}$ resveratrol (Figure $5 \mathrm{~A}$ ). When $20 \mathrm{M}$ of 
A

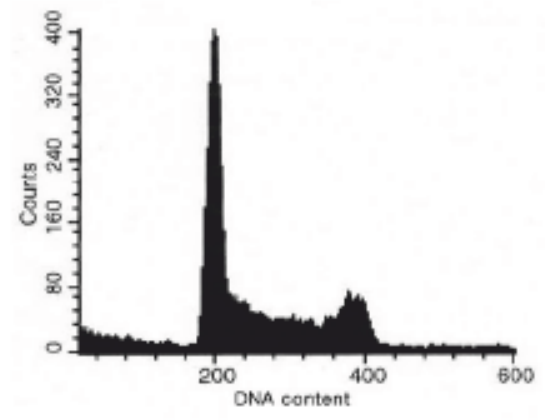

B

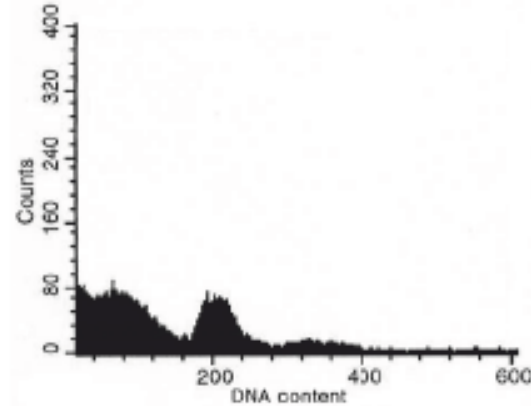

C

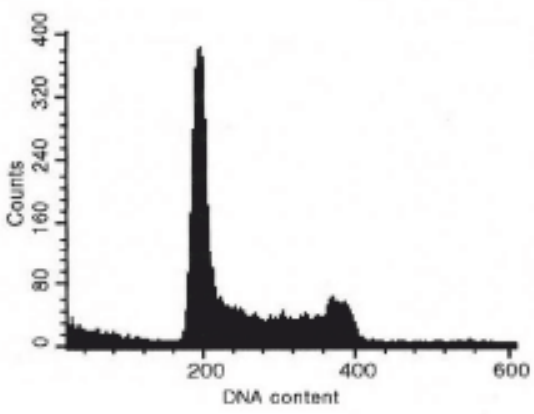

D

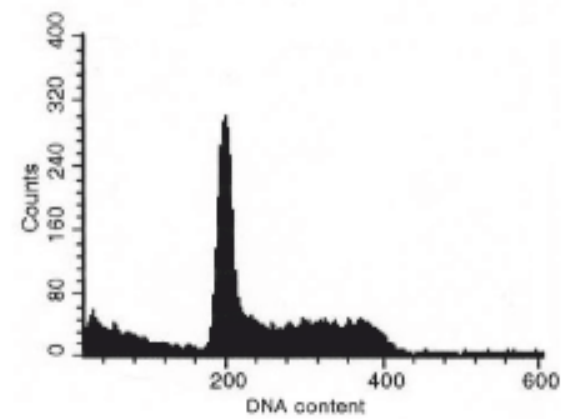

E

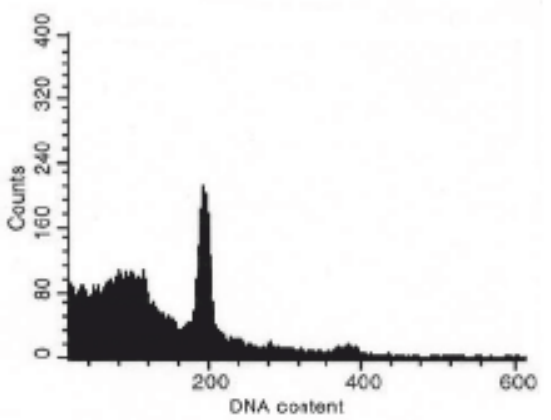

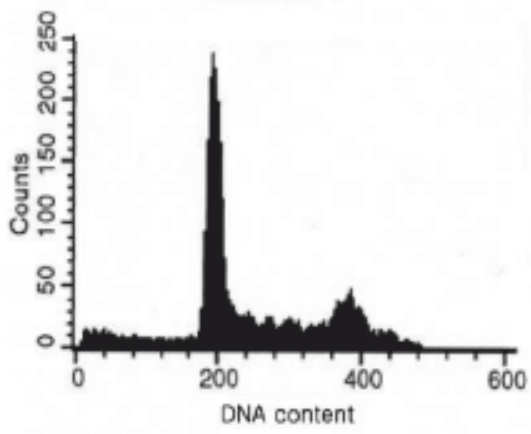
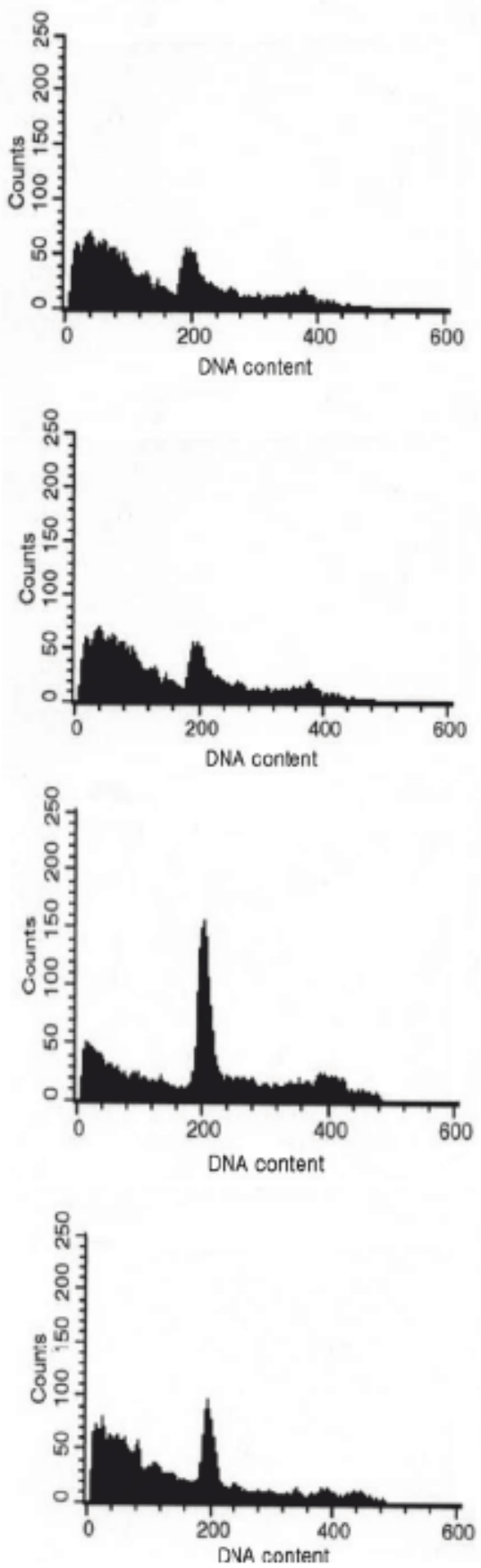

Figure 4. Flow cytometric analysis of cell cycle distribution in HL-60 cells treated with $25 \mu \mathrm{M}$ (left) and $100 \mu \mathrm{M}$ (right) resveratrol and its derivatives (A: control, B: resveratrol, C: viniferin, D: gnetin $\mathrm{H}, \mathrm{E}$ : suffrutcosol B) for $24 \mathrm{~h}$. Cell cycle analysis was performed on an equal number of cells $\left(10^{\circ}\right)$ were fixed and staining of DNA by propidium iodide. 
Table 1. Flow cybmetric analysis of cell cycle distibution in HL-60 cells treated with $100 \mu \mathrm{M}$ resveratrol for the time indicated.

\begin{tabular}{rrrrr}
\hline & \multicolumn{4}{c}{ Cell cycle analysis (\%) } \\
\cline { 2 - 5 } Time (h) & Sub G1 & G1 & \multicolumn{1}{c}{ S } & G2/M \\
\hline 0 & 9.0 & 50.3 & 24.5 & 15.0 \\
6 & 40.9 & 42.1 & 9.4 & 6.7 \\
16 & 49.4 & 36.9 & 6.8 & 6.3 \\
24 & 70.5 & 21.3 & 4.0 & 3.7 \\
\hline
\end{tabular}

the four stilbenes was treated for $5 \mathrm{~h}$, resveratrol and suffruticosol $B$, but not viniferin and gnetin $\mathrm{H}$, markedly suppressed CYP1B1 mRNA expression (Figure $5 B)$.

\section{Discussion}

The present study demonstrated that like resveratrol, its dimers and trimers such as viniferin, gnetin $\mathrm{H}$, and suffruticosol B also exerted strong cytotoxic activity in human leukemia HL- 60 cells and induced apoptosis. We recently observed that resveratrol oligomers isolated from peony seeds inhibited growth of C6, HepG2, Hela, MCF-7 and HT-29 cancer cells in a concentration-dependent manner (Kim et al., 2002b). Ohyama et al. (1999) also evaluated several resveratrol oligomers isolated from plants, and found hopeaphenol, a resveratrol trimer, showed potent cytotoxicity against a few human cancer cell lines. Cytotoxic activities of resveratrol oligomers were variable in different cancer cell types.

In the present study, HL-60 cell death induced by resveratrol and its derivatives was due to the apoptosis. After treatment of resveratrol and its derivatives, we observed the typical morphological characteristics of apoptosis, such as chromatin condensation and widespread formation of apoptotic bodies. In addition, internucleosomal DNA fragmentation as determined by agarose gel electrophoresis and kinetic analysis of cell cycle distribution by flow cytometry also clearly revealed that resveratrol and its derivatives rapidly induced apoptotic cell death. Previous studies showed the apoptotic effects of resveratrol in $\mathrm{HL}-60$ cells (Surh et al., 1999; Joe et al., 2002) and in melanoma cells (Niles et al., 2003), and vaticanol C, a resveratrol tetramer, in colon cancer cell lines (Ito et al., 2002). Howerver, the present study is the first demonstration of resveratrol dimers and trimers-induced potent apoptotic HL-60 cell death.

Among four stilbenes examined, results of the MTT assay showed that suffruticosol B, a resveratrol

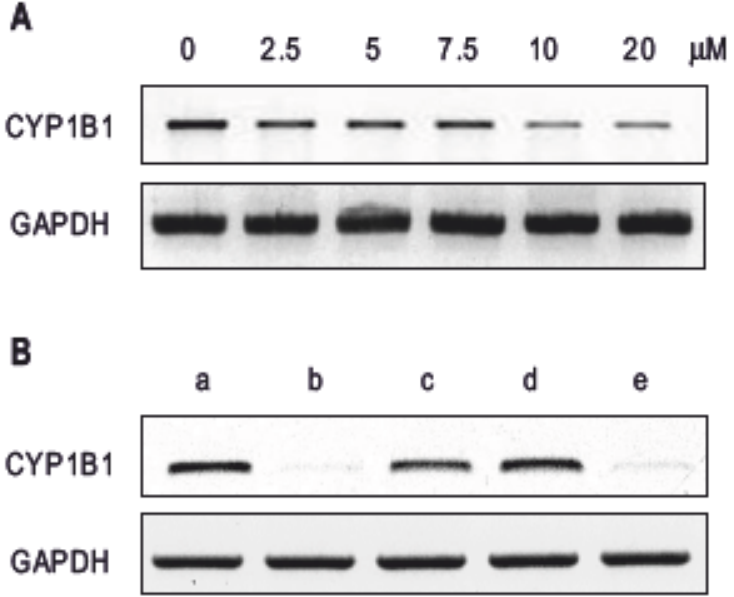

Figure 5. Cytochrom P450 $1 \mathrm{~B} 1$ (CYP1B1) gene expression in HL-60 cells treated with 2.5-20 $\mu \mathrm{M}$ resveratrol (A) and vehide (a), $20 \mu \mathrm{M}$ resveratrol (b), viniferin (c) and suffuticosol B (d) for $5 \mathrm{~h}$ (B). RTPCR was carried out with $10 \mu \mathrm{g}$ of RNA as described in Materials and Methods.

trimer, exhibited the most potent inhibitory activity with $I_{50}$ value of $20 \mu \mathrm{M}$, whereas $I C_{50}$ value of resveratrol was approximately $95 \mu \mathrm{M}$. However, the FACS analysis showed that treatment of $25 \mu \mathrm{M}$ resveratrol and suffruticosol B for $24 \mathrm{~h}$ induced similar degree of extensive apoptosis. Reasons for the different sensitivity of resveratrol on inhibiting cell growth and inducing apoptosis in HL-60 cells are not clear, but might be due at least partly to methodological pitfalls in the use of MTT assay for evaluating cell growth. It has been recognized that phytoestrogens such as resveratrol (Bernhard et al., 2003) and genistein (Pagliacci et al., 1993) enhance mitochondrial MTT-reducing activity at low concentration ranges of 5-20 $\mu \mathrm{M}$ without a corresponding increase in the number of living cells. This phenomenon may underestimate growth inhibitory effects of resveratrol in certain cancer cells. However, low concentrations of resveratrol dimer and trimers, not like resveratrol, strongly decreased the MTT-reducing activity in the present study.

Various anticancer agents induce cell cycle arrest in some human cancer cell lines (Shi et al., 1996; Ragione et al., 1998; Joe et al., 2002), suggesting a possible role for cell cycle arrest in apoptosis. Resveratrol has been reported to block the $S-G_{2}$ transition and arrest the $\mathrm{S}$ phase of the cell cycle in HL-60 cells (Ragione et al., 1998; Joe et al., 2002). The present study showed a gradual reduction in the proportion of cell cycle in the $G_{1}, S$ and $G_{2} / M$ phases with concomitant increase in the percentage of sub- $\mathrm{G}_{1}$ phase as reported by Surh et al. (1999). Since concentrations required for resveratrol to induce apoptosis were often higher than those that induced 
cell cycle arrest, we might not observe the arrest in the S-phase prior to apoptosis.

The cytochrome P450 enzyme CYP1B1 has been recognized to be highly expressed in a wide variety of human tumors of different organs, but not detected in the corresponding normal tissues (Murray et al., 1997). The CYP1B1 activates procarcinogens into carcinogens (Shimada et al. 1996; Kim et al., 1998), thus it has been suggested as the cause of tumors and a potential target for chemoprevention strategies. Resveratrol inhibited the catalytic activity and constitutive gene expression of human CYP1B1 in MCF-7 human breast cancer cells (Chang et al., 2000). The present study also showed resveratrol-induced suppression of CYP1B1 mRNA expression in a dosedependent manner in HL-60 cells. When four stilbenes were treated, resveratrol and suffruticosol $B$, but not viniferin and gnetin $\mathrm{H}$, markedly decreased CYP1B1 mRNA expression. Flow cytometric analysis also showed that resveratrol and suffruticosol B induced a stronger apoptotic cell death than viniferin and gnetin $H$ in $H L-60$ cells. These results suggest a possibility that resveratrol and its derivatives, particularly suffruticosol B, may protect against toxicity and carcinogenicity induced by compounds that undergo CYP1B1catalyzed bioactivation. In contrast, Potter et al. (2002) recently demonstrated that CYP1B1 catalyzes resveratrol to piceatannol that has antileukemic activity. They hypothesized that the functional role of CYP1B1 is a tumor suppressor enzyme, or 'rescue enzyme' that is a molecular mechanism for the anticancer properties of resveratrol. However, further studies are required to elucidate the functional role of CYP1B1 in cancer cells.

In summary, resveratrol derivatives, particularly suffruticosol B, as shown by resveratrol exerted potent cytotoxic and proapoptotic activities, and suppressed gene expression of CYP1B1 in HL-60 cells. Further studies are required to investigate underlying mechanisms of the apoptosis-inducing activity of resveratrol derivatives in diverse cancer cell lines and to ascertain if resveratrol derivatives exert anticarcinogenic activity in vivo.

\section{Acknowledgement}

This work was supported by a research grant of the Korea Health 21 R\&D Project, Ministry of Health \& Welfare, Republic of Korea (HMP-00-B22000-0152).

\section{References}

Bernhard D, Schwaiger W, Crazzolara R, Tinhofer I, Kofler R, Csordas A. Enhanced MTT-reducing activity under growth inhibition by resveratrol in $\mathrm{CEM}-\mathrm{C} 7 \mathrm{H} 2$ lymphocytic leukemia cells. Cancer Lett 2003;195:193-9

Bowers JL, Tyulmenkov W, Jernigan SC, Klinge CM. Resveratrol acts as a mbed agonist/antagonist for estrogen receptors alpha and beta. Endocrinology 2000;141:3657-67

Chang ST, Wang DS, Wu CL, Shiah SG, Kuo YH, Chang CJ. Cytotoxicity of extractives from Taiwania cryptomerioides heartwood. Phytochem 2000;55:227-32

Damianaki A, Bakogeorgou E, Kampa M, Notas G, Hatzoglou A, Panagiotou S, Gemetzi C, Kouroumalis E, Martin PM, Castanas E. Potent inhibitory action of red wine polyphenols on human breast cancer cells. J Cell Biochem 2000; 78:429-41

Dorrie J, Gerauer H, Wachter Y, Zunino SJ, Resveratrol induces apoptosis by depolarizing mitochondrial membranes and activating caspase-9 in acute lymphoblastic leukemia cells. Cancer Res 2001;61:4731-9

Gautam SC, $X u$ YX, Dumaguin M, Janakiraman N, Chapman RA. Resveratrol selectively inhibits leukemia cells: a prospective agent for ex viso bone marrow purging. Bone Marrow Transplant 2000;25:639-45

Gehm BD, McAndrews JM, Chien PY, Jameson JL. Resveratrol, polyphenolic compound found in grapes and wine, is an agonist for the estrogen receptor. PNAS 1997;94:1413843

Hannun YA. Apoptosis and the dilemma of cancer chemotherapy. Blood 1997;89:1845

Herrmann M, Lorena HM, Granke R, Vol M, Woith W, Kalden JR. A rapid and simple method for the isolation of apoptotic DNA fragments. Necleic Acid Res 1994;22:5506-7

Ito $T$, Akao $Y$, Tanaka $T$, Inuma $M$, Nozawa $Y$. Vaticanol $C$, a novel resveratrol tetramer, inhibits cell growth through induction of apoptosis in colon cancer cell lines. Biol Pharm Bull 2002;25:147-8

Jang $M$, Cai L, Udeani GO, Slowing KV, Thomas CF, Beecher $\mathrm{CW}$, Fong $\mathrm{HH}$, Farnsworth NR, Kinghorm AD, Mehta RG, Moon RC, Pezzuto JM. Cancer chemopreventive activity of resveratrol, a natural product derived from grapes. Science $1997 ; 275 ; 218-20$

Joe AK, Liu H, Suzui M, Vural ME, Xiao D, Weinstein IB. Resveratrol induces growth inhibition, S-phase arrest, apopbsis, and changes in biomarker expression in several human cancer cell lines. Clin Cancer Res 2002;8:893-903

Kim HJ, Chang EJ, Cho SH, Chung SK, Park HD, Choi SW. Antioxidative activity of resveratrol and its derivatives isolated from seeds of Paeonia lactiflora. Biosci Biotechnol Biochem 2002a;66:1990-3

Kim HJ, Chang EJ, Bae SJ, Shim SM, Park HD, Rhee CH, Park JH, Choi SW. Cytotoxic and antimutagenic stilbenes from seeds of Paeonia lactiflora. Arch Pharm Res 2002b;25: 293-9

Kim JH, Stansbury KH, Walker NJ, Trush MA, Strickland PT, Sutter TR. Metabolism of benzopyrene and benzopyrene-7, 8 -diol by humnan cytochrome p4501B1. Carcinogen 1998;19: 1847.53

Krammer PH, Behrmann I, Daniel P, Dhein J, Debatin KM. Regulation of apoptosis in the immune system. Curr Opin 
Immunol 1994;6:279-89

Mitchell SH, Zhu W, Young CY. Resveratrol inhibits the expression and function of the androgen receptor in $\mathrm{LNCaP}$ prostate cancer cells. Cancer Res 1999;59:5892-5

Murray GI, Taylor MC, McFadyen MCE, Mckay JA, Greenlee WF, Burke MD, Melvin WT. Tumor-specific expression of cytochrome P450 1B1. Cancer Res 1997;57:3026-31

Niles RM, McFarland M, Weimer MB, Redkar A, Fu YM, Meadows GG. Resveratrol is a potent inducer of apoptosis in human melanoma cells. Cancer Lett 2003;190:157-63

Ohyama M, Tanaka $T$, It $T$, linuma $M$, Bastow KF, Lee KH. Cytotoxicity of naturally occurring resveratrol oligomers and their acetate derivatives. Bioorg Med Chem Lett 1999;305760

Pagliacci MC, Spinozzi F, Migliorati G, Fumi G, Smacchia $M$, Grignani F, Riccardi C, Nicoletti I. Genistein inhibits tumour cell growth in vitro but enhances mitochondrial reduction of tetrazolium salts: a further pitfall in the use of the MTT assay for evaluating cell growth and survival. Eur $\mathrm{J}$ Cancer 1993;29A:1573-7

Park JA, Lee KY, Oh YJ, Kim KW, Lee SK. Action of caspase-3 protease via a $\mathrm{Bcl}-2$ insensitive pathway during the process of ginsenoside Rh2-induced apoptosis. Cancer Lett $1997 ; 121: 73-81$

Potter GA, Patterson LH, Burke MD. Aromatic hydroxylation activated (AHA) prodrugs. US Patent 2001;6,214,886

Ragione FD, Cucciolla V, Borriello A, Pletra VD, Racioppi L, Soldati G, Manna C, Galletti P, Zappia V. Resveratrol arrest the cell division cycle at S/G2 phase transition. Biochem Biophys Res Commun 1998;250:53-8

Schneider $Y$, Vincent F, Duranton B, Badolo L, Gosse F, Bergmann C, Seiler N, Raul F. Antiproliferative effect of resveratrol, a natural component of grapes and wine, on human colonic cancer cells. Cancer Lett 2000;159:85-91

Shi L, Chen G, He D, Bosc DG, Litchfield DW, Greenberg AH. Granzyme B induces apoptosis and cyclinA-associated cyclin-dependent kinase activity in all stages of the cell cycle. $J$ Immunol 1996;157:2381-5

Shimada T, Hayes CL, Yamazaki H, Amin S, Hecht SS, Guengerich FP, Sutter TR. Activation of chemically diverse procarcinogens by human cytochrome P-450 1B1. Cancer Res $1996 ; 56: 2979-84$

Sotheeswaran S, Pasupathy V. Review article number 74: Distribution of resveratrol oligomers in plants. Phytochemistry 1993;32:1083-92

Surh YJ, Hurh YJ, Kang JY, Lee EY, Kong G, Lee SJ. Resveratrol, an antioxidant present in red wine, induces apoptosis in human promyelocytic leukemia $(\mathrm{HL}-60)$ cells. Cancer Lett. 1999;140:1-10

Thompson CB. Apoptosis in the pathogenesis and treatment of disease. Science 1995;267:1456-62

Wang $M$, Jin $Y$, Ho CT. Evaluation of resveratrol derivatives as potential antioxidants and identification of a reaction product of resveratrol and 2,2-diphenyl-1-picryhydrazyl radical. J Agric Food Chem 1999;47:3974-7

Watabe M, Mansuda $Y$, Nakajo S,Yoshida T, Kurowa T, Nakaya $Y$. The cooperative interaction of two different signalling pathways in response to bufalin induces apoptois in human leukemia U937 cells. J Biol Chem 1996;271:14067-80

White E. Life, death and the pursuit of apoptosis. Genes Dev $1996 ; 10: 1-15$

Xia ZQ, Costa MA, Pelissier HC, Davin LB, Lewis NG. Secoisolariciresinol dehydrogenase purification, cloning, and functional expression implications for human health protection. J Biol Chem 2001;276:12614-23 